\title{
Jurist-Diction
}

Volume 4 No. 6, November 202

\section{Central Bank Digital Currency (CBDC) Sebagai Alat Pembayaran di Indonesia}

\author{
Claudia Saymindo Emanuella \\ claudia.se.purba@gmail.com \\ Universitas Airlangga
}

How to cite:

Claudia Saymindo Emanuella, 'Central Bank Digital Currency (CBDC) Sebagai Alat Pembayaran di Indonesia' (2021) Vol. 4 No. 6 JuristDiction.

Histori artikel:

Submit 6 Agustus 2021; Diterima 15 Oktober 2021; Diterbitkan 5 November 2021.

DOI:

10.20473/jd.v4i6.31845

p-ISSN: 2721-8392

e-ISSN: $2655-8297$

\section{Abstract}

Technological developments encourage innovation in various sectors, including banking. The widespread use of digital currencies is an impetus for central banks to create an alternative to replace ungoverned digital currencies. Central Bank Digital Currency (CBDC) is the alternative chosen by various central banks in the world. Various countries have conducted research related to the implementation in terms of design and risk in the financial, operational, and legal fields. Bank Indonesia plans to develop a CBDC as part of national economy and finance digitalization. Indonesia does not yet have a strong legal framework to underlie the implementation of $C B D C$, especially in the cyber security sector, The role of the central bank becomes very important in $C B D C$ 's issuance and implementation as the only party that has the right to determine, issue, and regulate legal payment instruments in Indonesia.

Keywords: Central Bank Digital Currency; Digital Money; Central Bank; Cybersecurity.

\begin{abstract}
Abstrak
Perkembangan teknologi mendorong inovasi dalam berbagai sektor, termasuk perbankan. Maraknya penggunaan digital currency menjadi dorongan bagi bank sentral untuk menciptakan mata uang digital yang dapat menggantikan digital currency tanpa pihak berwenang. Central Bank Digital Currency (CBDC) menjadi alternatif yang dipilih oleh berbagai bank sentral di dunia, dan berbagai negara telah melakukan riset terkait penerapan CBDC dari sisi desain dan risiko di bidang finansial, operasional, dan legal. Bank Indonesia berencana untuk mengembangkan CBDC di Indonesia sebagai bagian dari digitalisasi ekonomi dan keuangan nasional. Indonesia belum memiliki kerangka hukum yang kuat untuk mendasari penerapan CBDC, terutama dalam bidang keamanan siber, mengingat banyaknya ancaman keamanan siber canggih yang terus berkembang. Peran bank sentral menjadi sangat penting dalam penerbitan dan penerapannya sebagai satu-satunya pihak yang berhak menentukan, menetapkan, menerbitkan, dan meregulasi alat pembayaran sah di Indonesia.

Kata Kunci: Central Bank Digital Currency; Uang Digital; Bank Sentral; Cybersecurity.
\end{abstract}

Copyright $@ 2021$ Claudia Saymindo Emanuella 


\section{Pendahuluan}

Sistem Pembayaran adalah sistem yang mencakup seperangkat aturan, lembaga, dan mekanisme yang dipakai untuk melaksanakan pemindahan dana, guna memenuhi suatu kewajiban yang timbul dari suatu kegiatan ekonomi. ${ }^{1}$ Seiring dengan berjalannya waktu, teknologi yang terus berkembang memberi dampak yang signifikan dalam kehidupan masyarakat, termasuk dalam pelaksanaan sistem pembayaran. Munculnya teknologi finansial (financial technology / fintech) menjadi salah satu faktor terbesar dalam pelaksanaan sistem tersebut. Makin banyak masyarakat yang lebih memilih untuk bertransaksi menggunakan uang elektronik dibandingkan uang kartal sebagai alat untuk transaksi pembayaran. Hal ini dibuktikan dengan pertumbuhan transaksi uang elektronik terus meningkat, sebagaimana pada Januari 2020 tercatat sebesar 172,85\% (year on year/yoy). ${ }^{2}$

Perkembangan teknologi finansial memudahkan masyarakat dalam melakukan transaksi, baik untuk kepentingan jual beli, transfer dana, atau membayar tagihan. Mulai dari penggunaan kartu debet atau kredit yang digesekkan ke mesin EDC (Electronic Data Capture) hingga penggunaan e-wallet seperti Go-Pay, OVO, Dana, dan ShopeePay, menjadi pilihan alternatif untuk bertransaksi finansial tanpa perlu membawa sejumlah besar nominal uang tunai saat berpergian. Terlebih semenjak adanya pandemi Covid-19 yang mengharuskan limitasi kontak. Bank Indonesia mencatat nilai transaksi uang elektronik mencapai Rp 20,7 triliun pada Januari 2021. Jumlah tersebut meningkat 30,7\% dibandingkan periode yang sama pada tahun sebelumnya sebesar Rp 15,9 triliun. $^{3}$

Salah satu inovasi dalam teknologi finansial adalah munculnya mata uang digital atau virtual currency / cryptocurrency. Cryptocurrency adalah mata uang

\footnotetext{
${ }^{1}$ Bank Indonesia, 'Sistem Pembayaran \& Pengelolaan Uang Rupiah’ (Bank Indonesia, 2021) https://www.bi.go.id/id/fungsi-utama/sistem-pembayaran/default.aspx, dikunjungi pada 26-032021.

2 Giri Hartono, 'BI Catat Penggunaan Uang Elektronik Tumbuh 172,85\%' (Okezone, 2020) <https://economy.okezone.com/read/2020/02/20/320/2171484/bi-catat-penggunaan-uangelektronik-tumbuh-172-85>, dikunjungi pada 26-03-2021.

${ }^{3}$ Andrea Lidwina, 'Nilai Transaksi Uang Elektronik Naik 30\% pada Awal 2021' (Katadata, 2021) <https://databoks.katadata.co.id/datapublish/2021/03/04/nilai-transaksi-uang-elektroniknaik-30-pada-awal-2021> dikunjungi pada 26-07-2021.
} 
digital Peer-to-Peer (P2P) yang dapat diprogram dan memungkinkan pembayaran online dikirim langsung dari satu pihak ke pihak lain tanpa melalui perantara. ${ }^{4}$ Bank Indonesia mendefinisikan cryptocurrency sebagai mata uang digital yang diterbitkan oleh pihak lain selain otoritas moneter dan diperoleh dengan cara mining, pembelian, atau transfer pemberian (reward). Cara kerja cryptocurrency adalah melalui blockchain, suatu database berisi daftar catatan informasi atau record (yang juga disebut block) digital yang terus berkembang. Fungsi dari blockchain sama seperti pembukuan pada umumnya, yaitu untuk mencatat transaksi, debit, dan kredit antara pihak (seperti penjual dan pembeli). Cara blockchain bekerja adalah dengan sistem distribusi data. Mudahnya, saat seseorang ingin menambahkan suatu data dalam jaringan blockchain-nya, maka data tersebut akan diverifikasi dan kemudian di-approve oleh semua pihak yang berada dalam jaringan tersebut. Data itu kemudian akan terdistribusikan ke seluruh pihak dalam jaringan setelah proses verifikasi dan approval selesai. Awalnya, sistem blockchain diciptakan sebagai sistem transparan untuk beroperasi di Bitcoin yang merupakan jenis cryptocurrency yang paling dikenal masyarakat luas. Sebagai uang digital, kepemilikan Bitcoin dicatat pada buku besar elektronik yang diperbarui hampir secara bersamaan pada sekitar 10.000 (sepuluh ribu) komputer di seluruh dunia yang saling terhubung dan dioperasikan secara independen. "Buku besar elektronik" inilah yang berkembang menjadi blockchain.

Sebagai bank sentral, salah satu tugas dan fungsi Bank Indonesia adalah untuk mengatur dan menjaga kelancaran sistem pembayaran, sebagaimana diatur dalam Undang-Undang Nomor 23 Tahun 1999 tentang Bank Indonesia. Dengan berkembangnya teknologi, Bank Indonesia telah mengeluarkan beberapa peraturan terkait untuk meregulasi perkembangan tersebut, seperti Peraturan Bank Indonesia (PBI) Nomor 18/40/PBI/2016 tentang Penyelenggaraan Pemrosesan Transaksi

\footnotetext{
${ }^{4}$ David Lee Kuo Chuen \& Linda Low, 'Inclusive Fintech: Blockchain, Cryptocurrency, and ICO’ World Scientific Publishing (2018).[35].

5 Antony Lewis, 'The Basics of Bitcoins and Blockchains: An Introduction to Cryptocurrencies and the Technology that Powers Them' Mango Publishing (2018).
} 
Pembayaran dan Peraturan Bank Indonesia (PBI) Nomor 19/12/PBI/2017 tentang Penyelenggaraan Teknologi Finansial. Kedua peraturan tersebut secara tegas melarang penggunaan segala jenis mata uang digital. Pasal 34 huruf (a) PBI Nomor 18/40/PBI/2016 dengan jelas menyatakan bahwa "Penyelenggara Jasa Sistem Pembayaran dilarang melakukan pemrosesan transaksi pembayaran dengan menggunakan virtual currency". Salah satu alasan kuat yang mendasari keputusan pelarangan ini adalah karena tidak adanya otoritas yang dapat bertanggung jawab atas penggunaan virtual currency tersebut. Karena sistem desentralisasi dalam blockchain yang ditandai dengan penyebaran data kepada pihak-pihak (sehingga tidak terpusat), hal ini berarti tidak ada badan yang membawahi sistem jaringan yang digunakan. Jika muncul suatu konsekuensi akibat dari penggunaan virtual currency, tidak ada pihak yang dapat dimintai pertanggungjawabannya. Pengguna virtual currency sendiri bisa saja juga tidak memiliki informasi atau pengetahuan mengenai konsekuensi tersebut. Selain itu, virtual currency juga tidak memiliki underlying asset yang mendasari harganya dan nilai perdagangannya sangat fluktuaktif.

Beberapa negara memberikan pengertian terkait virtual / digital currency sebagai berikut: ${ }^{6}$

1. European Central Bank (2012): "A virtual currency is a type of unregulated, digital money, which is issued and usually controlled by its developers, and used and accepted among the members of a specific virtual community". (Mata uang virtual adalah jenis uang digital yang tidak diatur dan dikeluarkan serta dikendalikan oleh pengembangnya, dan digunakan serta diterima oleh anggota komunitas virtual tertentu).

2. Financial Action Task Force (2014): "Virtual currency is a digital representation of value that can be digitally traded and functions as (1) a medium of exchange; and/or (2) a unit of account; and/or (3) a store of value, but does not have legal tender status (i.e., when tendered to a creditor, is a valid and legal offer of payment) in any jurisdiction". (Mata uang virtual adalah representasi digital dari nilai yang dapat diperdagangkan secara digital dan berfungsi sebagai (1) alat tukar; dan / atau (2) satuan rekening; dan / atau (3) penyimpan nilai, tetapi tidak memiliki status tender yang sah di yurisdiksi manapun).

${ }^{6}$ Muhammad Edhie Purnawan \& Retno Riyanti, 'Significant Effect of the Central Bank Digital Currency on the Design of Monetary Policy’ (2019) 8 Jurnal Ekonomi Indonesia.[129]. 
3. Committee on Payments and Market Infrastructures (CPMI): "Digital currency as any electronic form of money, or medium of exchange that features a distributed ledger and a decentralized payment system." (Mata uang digital sebagai segala bentuk uang elektronik, atau alat tukar dengan buku besar yang didistribusikan dan sistem pembayaran yang terdesentralisasi).

4. Bank for International Settlements (2015): "Digital currency is an asset stored in electronic form that can serve essentially the same function as physical currency, namely, facilitating payments transactions." (Mata uang digital adalah aset yang disimpan dalam bentuk elektronik yang pada dasarnya dapat berfungsi sama dengan mata uang fisik, yaitu memfasilitasi transaksi pembayaran).

Mengingat sistem virtual currency yang relatif tidak aman karena berpengaruh terhadap stabilitas moneter, pemerintah di berbagai negara terinspirasi untuk menciptakan suatu mata uang digital yang lebih aman dengan pertanggungjawaban yang jelas, yaitu Central Bank Digital Currency (CBDC). Berbeda dengan virtual currency yang sistemnya bersifat desentralisasi, CBDC diterbitkan dan diregulasi oleh bank sentral seperti uang kartal maupun uang elektronik.

CBDC mengacu pada mata uang yang memenuhi kriteria berikut: ${ }^{7}$

1. The central bank issues it in digital form. (Bank sentral menerbitkannya dalam bentuk digital).

2. Anyone has the right to hold it. It is not a privilege reserved to, e.g. credit institutions. (Siapapun berhak memegangnya. Ini bukan hak istimewa seperti hanya untuk lembaga kredit).

3. It is the same currency as banknotes and central bank deposits. The conversion rate of Bank notes and zero-interest bearing digital cash would always be oneto-one, and at least some economic entities, e.g. banks, could convert it freely into other types of central bank money. (Mata uang yang sama dengan uang kertas dan deposito bank sentral. Tingkat konversi uang kertas dan uang digital tanpa bunga akan selalu satu banding satu, dan setidaknya beberapa entitas ekonomi, seperti bank, dapat mengubahnya secara bebas menjadi jenis uang bank sentral lainnya).

4. It can be used as a payment instrument in retail payments. (Dapat digunakan sebagai alat pembayaran dalam pembayaran retail).

5. When two parties engage in a transaction, there is no third party-at least not a private one - that verifies or executes the payment as a central counterparty. The same principle applies to banknote payments. (Ketika dua pihak terlibat dalam suatu transaksi, tidak ada pihak ketiga yang memverifikasi atau melaksanakan pembayaran sebagai rekan utama. Prinsip yang sama berlaku untuk pembayaran dengan uang kertas).

${ }^{7}$ Aleksi Grym, et.al., 'Central Bank Digital Currency’ (2017) BoF Economics Review.[2]. 
Sejak April 2020, negara Cina telah melakukan percobaan atas CBDC mereka yang disebut Digital Currency / Electronic Payment (DC/EP). Penggunaan uang kartal di Cina semakin berkurang dari tahun ke tahun, dimana pada tahun 2016 hanya $40 \%$ dari seluruh transaksi dilakukan dengan uang kartal. ${ }^{8}$ Hal ini mendorong pemerintah Cina untuk menciptakan alternatif pembayaran sebagai pengganti uang kartal, yaitu dengan mengeluarkan DC/EP. ${ }^{9}$ Selain Cina, Swedia juga mengalami berkurangnya penggunaan uang kartal dan memprediksi akan menjadi negara cashless pada tahun 2023. Mereka melakukan uji coba CBDC yang dinamai e-krona sebagai pengganti uang kartal sejak 2020 sampai Februari 2021 yang lalu dan kini sedang mencoba untuk memutuskan apakah e-krona akan terus dikeluarkan. ${ }^{10}$ Beberapa negara lain juga sudah atau sedang melangsungkan uji coba atas penggunaan CBDC, seperti Perancis, Filipina, Jepang, Turki, dan Swiss. Sampai saat ini masih belum ada negara yang benar-benar menerapkan CBDC dan masih meneliti dampak positif dan negatifnya, tetapi seiring dengan berjalannya waktu semakin banyak negara yang tertarik untuk menerapkannya.

Saat ini Bank Indonesia sedang merumuskan pembentukan CBDC untuk membendung maraknya penggunaan virtual currency. Bank Indonesia melakukan kajian untuk melihat potensi dan manfaat CBDC, yang nantinya akan menentukan perbedaan desain dan arsitektur CBDC yang akan dipilih serta mitigasi risikonya. ${ }^{11}$ Sejauh ini Bank Indonesia baru mengeluarkan Peraturan Bank Indonesia Nomor 20/6/PBI/2018 yang meregulasi Uang Elektronik. Berbeda dengan CBDC yang berfungsi sebagai mata uang tersendiri, uang elektronik diterbitkan berdasarkan nilai uang yang disetor terlebih dahulu dan disimpan secara elektronik. Dengan kata

\footnotetext{
${ }^{8}$ Jonas Gross, 'CBDC pioneers: Which countries are currently testing a retail central bank digital currency?' (University of Bayreuth, 2020) <https://jonasgross.medium.com/cbdc-pioneers-which-countries-are-currently-testing-a-retail-central-bank-digital-currency-49333be477f4\#: : text $=$ Our\%20analysis\%20shows\%20that $\% 20$ China,pioneers $\% 20$ in $\% 20$ the $\% 20$ CBDC\%20space>, dikunjungi pada 28-03-2021.

${ }^{9}$ ibid.

${ }^{10}$ ibid.

${ }^{11}$ Herlina Kartika Dewi, 'Rumuskan uang digital, BI akan bikin Central Bank Digital Currency (CBDC)' (Kontan, 2021) < https://nasional.kontan.co.id/news/rumuskan-uang-digital-biakan-bikin-central-bank-digital-currency-cbdc >, dikunjungi pada 28-03-2021.
} 
lain, peraturan yang sudah ada baru meregulasi mata uang rupiah yang disimpan secara elektronik di media server.

Bank for International Settlements (BIS) telah mengeluarkan 2 panduan terkait CBDC ini, yaitu:

1. Central bank digital currencies: foundational principles and core features;

2. Committee on Payments and Market Infrastructures: Digital currencies.

Dari kedua panduan tersebut, masih diperlukan kajian terkait penerapan digital currency di Indonesia, agar tetap terjamin kepastian hukum dan stabilitas moneter di Indonesia yang merupakan fungsi dari Bank Indonesia selaku bank sentral.

Berdasarkan latar belakang penulisan di atas, adapun rumusan masalah yang akan diangkat sebagai topik pembahasan, yaitu:

1. Karakteristik Central Bank Digital Currency;

2. Tanggung jawab bank sentral sebagai penyelenggara Central Bank Digital Currency.

\section{Metode Penelitian}

Tipe penelitian hukum yang digunakan dalam penelitian ini adalah penelitian hukum normatif / doktrinal. Menurut Peter Mahmud, "Penelitian doktrinal, yaitu penelitian yang menyediakan ekspos sistematis terhadap peraturan yang mengatur kategori hukum tertentu, menganalisis hubungan antar peraturan, menjelaskan area yang mengalami hambatan, dan bahkan memperkirakan perkembangan mendatang". ${ }^{12}$

Pendekatan yang digunakan adalah pendekatan perundang-undangan (statute approach) yang dilakukan dengan menganalisis, menelaah, dan mengkaji peraturan perundang-undangan yang berkaitan dengan rumusan masalah tersebut, pendekatan perbandingan (comparative approach) yang dilakukan dengan membandingkan hukum suatu negara dengan hukum negara lain atau hukum dari suatu waktu

\footnotetext{
${ }^{12}$ Peter Mahmud Marzuki, Penelitian Hukum (Kencana Prenada Media 2017).[32].
} 
tertentu dengan hukum dari waktu yang lain, serta pendekatan konseptual (conceptual approach) yang dilakukan tanpa beranjak dari peraturan hukum yang ada dikarenakan aturan hukum untuk permasalahan memang belum ada.

\section{Asal Mula Uang Digital}

Sebagai makhluk sosial, manusia membutuhkan orang lain selain dirinya sendiri. Baik untuk kebutuhan fisik maupun psikis, tidak ada seorangpun yang mampu bertahan hidup sendirian. Sebelum uang pertama kali muncul, manusia saling bertukar barang dan jasa dengan barang dan jasa lainnya untuk memenuhi kebutuhan hidupnya masing-masing. Seiring berjalannya waktu, sistem ini menjadi sulit diterapkan karena adanya ketidakseimbangan nilai tukar antara barang atau jasa yang ditawarkan. Sebagai solusi, beberapa benda ditetapkan sebagai alat tukar. Benda-benda ini umumnya memiliki nilai yang tinggi dan dibutuhkan oleh orangorang, seperti garam atau bahkan hewan ternak. Solusi ini tidak bertahan lama karena daya tahannya tidak lama. Seiring dengan perkembangan zaman, akhirnya manusia menggunakan logam mulia berupa emas dan perak sebagai alat tukar. Proses tersebut berdasarkan atas kelangkaan yang masuk akal dan tidak mudah rusak dalam waktu yang relatif lama, serta mudah digunakan dan dapat diterima berbagai pihak. ${ }^{13}$

Masalah lain muncul ketika jumlah logam mulia yang digunakan untuk transaksi menjadi terlalu banyak dan sulit untuk digunakan. Maka, mereka menitipkan uang-uangnya pada penyimpanan-penyimpanan tukang emas, tempat penukaran emas, atau pemuka-pemuka agama. Pihak-pihak itu kemudian memberikan akta berbentuk kertas (banknote), yaitu janji pihak penerima titipan (bank promise) untuk membayarkan uang logam kepada pemilik kertas ini ketika ada permintaan. ${ }^{14}$ Akta ini berperan sebagai alat bukti kepemilikan dan penyimpanan yang aman. Lama kelamaan, banknote yang diterbitkan ini makin

\footnotetext{
${ }^{13}$ Ahmad Hasan, Mata Uang Islami (PT. Raja Grafindo Persada 2005).[62-63].

${ }^{14}$ Difi Dahliana, 'Sejarah Uang' (UIN Antasari, 2021) < https://doi.org/10.17605/OSF.IO/ WS8JE $>$, dikunjungi pada 30-05-2021.
} 
banyak digunakan tanpa ditukarkan ke logam mulia yang direpresentasikan. Dari sinilah mulai terbentuk konsep uang kertas.

Seiring dengan perkembangan teknologi, konsep digitalisasi makin sering digunakan. Digitalisasi adalah proses pemindahan akitivitas dari bentuk fisik ke bentuk digital menggunakan teknologi. Keuntungan yang didapat dari proses ini adalah meningkatnya efisiensi, keamanan, dan kemudahan akses. Salah satu visi dan misi dari Presiden Joko Widodo adalah mempercepat digitalisasi di bidang ekonomi dan keuangan nasional. Sebagai bagian dari digitalisasi ekonomi, salah satu rencana yang disiapkan oleh Bank Indonesia adalah mendigitalisasikan uang. Kamus Besar Bahasa Indonesia (KBBI) mendefinisikan uang sebagai "alat tukar atau standar pengukur nilai (kesatuan hitungan) yang sah, dikeluarkan oleh pemerintah berupa kertas, emas, perak, atau logam lain yang dicetak dengan bentuk dan gambar tertentu.", sedangkan menurut Pasal 1 ayat (1) UU Mata Uang yang dimaksud dengan uang adalah alat pembayaran yang sah. Dengan adanya digitalisasi uang, definisi uang sendiri tidak akan terbatas pada bentuk fisik, melainkan juga dengan bentuk digital.

Tidak seperti uang kertas dan logam, uang digital hanya tersedia dalam bentuk digital atau elektronik, bukan dalam bentuk fisik. Uang kertas dan logam (uang kartal) dapat disimpan dalam rekening di bank sebagai bentuk deposit dan dapat ditransaksikan secara elektronik menggunakan kartu pembayaran. Meskipun tidak menggunakan wujud asli uang dalam transaksi, metode ini pada dasarnya tetap menggunakan bentuk uang kartal yang direpresentasikan, berbeda dengan uang digital. Uang digital merupakan mata uang tersendiri, seperti cryptocurrency, virtual currency, dan central bank digital currency (CBDC).

Saat ini salah satu jenis alat pembayaran yang marak digunakan adalah uang elektronik atau e-money. Pasal 1 ayat (3) PBI Uang Elektronik mendefinisikan Uang Elektronik sebagai instrumen pembayaran yang memenuhi unsur sebagai berikut:

a. diterbitkan atas dasar nilai uang yang disetor terlebih dahulu kepada penerbit;

b. nilai uang disimpan secara elektronik dalam suatu media server atau chip; dan c. nilai uang elektronik yang dikelola oleh penerbit bukan merupakan simpanan 
sebagaimana dimaksud dalam Undang-Undang yang mengatur mengenai perbankan.

Dalam PBI tersebut juga dijelaskan bahwa e-money dapat dibedakan berdasarkan media penyimpanan nilai uang dan pencatatan data identitas pengguna. Berdasarkan media penyimpanannya, e-money dibagi menjadi dua, yaitu:

a. Server based dengan media penyimpanan berupa server. Server based e-money menggunakan basis server sehingga pengguna harus terkoneksi dengan server internet penerbit e-money tersebut; dan

b. Chip based dengan media penyimpanan berupa chip. Chip based e-money menggunakan suatu chip yang ditanamkan langsung pada kartu, seperti kartu E-Toll.

Sedangkan berdasarkan pencatatan data identitas pengguna, e-money juga dibagi menjadi dua, yaitu:

a. Unregistered, dimana identitas pengguna tidak terdaftar dan tidak tercatat pada penerbit; dan

b. Registered, dimana identitas pengguna terdaftar dan tercatat di penerbit.

Beberapa provider e-money yang banyak digunakan di Indonesia seperti OVO, Go-Pay, dan DANA merupakan bentuk server based e-money dimana pengguna dapat menggunakannya melalui aplikasi di smartphone yang terhubung internet.

Berbeda dengan e-money yang saat ini beredar di masyarakat, CBDC merupakan mata uang tersendiri yang akan digunakan sebagaimana uang kertas dan uang giral. Laporan Committee on Payments and Market Infrastructures (CPMI) and the Markets Committee (MC) dari Bank for International Settlements pada tahun 2018 mendefiniskan CBDC sebagai varian baru uang bank sentral yang berbeda dari kas fisik atau rekening cadangan bank sentral. ${ }^{15}$

\section{Mekanisme Penerbitan CBDC}

Dengan cepatnya perkembangan teknologi, berbagai pihak telah lama mencari alternatif untuk sistem pembayaran yang dapat sepenuhnya terintegrasi.

\footnotetext{
${ }^{15}$ Christian Barontini \& Henry Holden, 'Proceeding with caution - a survey on central bank digital cuurency' (2019) 101 BIS Papers.[1].
} 
CBDC menjadi salah satu opsi yang dipertimbangkan karena tingkat keamanannya yang lebih terjamin dibandingkan dengan virtual currency, terutama dengan adanya larangan menggunakan cryptocurrency di Indonesia sebagaimana tertulis dalam PBI PPTP. Bank-bank sentral di berbagai negara, termasuk Indonesia, sedang mempertimbangkan berbagai tujuan untuk menerbitkan CBDC, seperti: ${ }^{16}$

a. Meningkatkan persaingan, efisiensi, dan ketahanan sistem pembayaran;

b. Mendukung digitalisasi keuangan, mengurangi biaya terkait pengeluaran dan pengelolaan kas fisik, meningkatkan inklusi keuangan;

c. Meningkatkan efektivitas kebijakan moneter untuk melaksanakan kebijakan yang ditargetkan;

d. CBDC berbunga dapat meningkatkan transmisi kebijakan moneter;

e. Mengurangi atau mencegah adopsi mata uang yang dikeluarkan secara pribadi (cryptocurrency);

f. Meningkatkan daya tarik mata uang lokal (mengurangi dolarisasi); dan

g. Berperan dalam penyaluran stimulus fiskal.

Sebelum menerbitkan mata uang baru, ada beberapa hal yang harus dipertimbangkan oleh bank sentral untuk menjamin keamanan dan stabilitas keuangan. Tidak hanya masyarakat sebagai target pengguna mata uang tersebut, pihak swasta seperti bank-bank lainnya juga turut menjadi bagian dari pertimbangan. Umumnya, ada tiga prinsip dasar yang menjadi pertimbangan bank sentral dalam penerbitan CBDC yang berdasarkan dari tujuan utamanya: ${ }^{17}$

a. Do no harm: Bentuk uang baru yang dikeluarkan oleh bank sentral harus mendukung pemenuhan tujuan kebijakan publik dan tidak mengganggu atau menghalangi kemampuan bank sentral menjalankan tugasnya dalam menjaga stabilitas moneter. Keberadaan CBDC harus memelihara dan memperkuat keseragaman mata uang, sehingga masyarakat dapat menggunakan CBDC dan uang tradisional secara bersamaan.

b. Coexistence: Berbagai jenis uang bank sentral, seperti CBDC atau uang yang sudah ada (uang tunai, deposit, atau settlement accounts) harus saling

\footnotetext{
${ }^{16}$ John Kiff, et.al., 'A Survey of Research on Retail Central Bank Digital Currency’ (2020), 104 IMF Working Paper.[39].

${ }^{17}$ Bank for International Settlements, 'Central bank digital currencies: foundational principles and core features' (BIS Papers, 2020) (selanjutnya disingkat Bank for International Settlements I). [10].
} 
melengkapi dan berdampingan dengan uang pribadi (misalkan rekening bank komersial) untuk mendukung tujuan kebijakan publik. Keberadaan CBDC bukan berarti dapat menghapus fungsi uang tunai, sehingga bank sentral harus terus menyediakan uang tunai selama diperlukan.

c. Innovation and efficiency: Tanpa inovasi dan persaingan untuk mendorong efisiensi dalam sistem pembayaran, masyarakat dapat terdorong untuk menggunakan instrumen pembayaran atau mata uang lain yang kurang aman, sehingga menyebabkan kerugian yang dapat merusak stabilitas moneter. Agen swasta dalam sistem pembayaran harus memiliki kebebasan untuk menentukan alat pembayaran yang mereka gunakan untuk transaksi.

Dari ketiga prinsip tersebut, BIS menyimpulkan 14 (empat belas) karakteristik dan fitur yang harus dimiliki CBDC. Fitur-fitur ini mencakup instrumen CBDC, sistem yang mendasarinya, dan institutional framework sebagai berikut: ${ }^{18}$

a. Convertible: Nilai tukar CBDC harus setara dengan uang yang sudah ada.

b. Convenient: Penggunaan $\mathrm{CBDC}$ harus semudah menggunakan uang tunai, kartu debit atau kredit, dan memindai kode melalui perangkat gawai.

c. Accepted and available: CBDC harus dapat digunakan untuk banyak jenis transaksi yang sama dengan uang tunai, termasuk vendor dan peer-to-peer seperti transaksi offline.

d. Low cost: Transaksi menggunakan CBDC harus berbiaya rendah atau gratis dan tidak memerlukan investasi teknologi khusus.

e. Secure: Infrastruktur dan pengguna CBDC harus aman dari serangan siber dan ancaman lainnya, termasuk dari pemalsuan.

f. Instant: Transaksi harus cepat dan instan.

g. Resilient: Sistem CBDC harus tahan terhadap gangguan operasional, bencana alam, pemadaman listrik, dan masalah lainnya. Jika terjadi gangguan koneksi jaringan, transaksi menggunakan $\mathrm{CBDC}$ harus dapat dilaksanakan offline.

h. Available: Sistem pembayaran menggunakan CBDC harus tersedia setiap saat.

i. Throughput: Sistem CBDC harus mampu memproses jumlah transaksi yang sangat tinggi.

j. Scalable: Untuk mengakomodasi potensi peningkatan pengguna atau perkembangan lainnya, sistem CBDC harus dapat dikembangkan pula.

k. Interoperable: Sistem CBDC bekerja sama dengan sistem dan pengaturan pembayaran digital sektor swasta untuk memungkinkan aliran dana antar sistem.

${ }^{18}$ ibid.[11]. 
1. Flexible and adaptable: Sistem CBDC harus fleksibel dan mudah beradaptasi terhadap perubahan kondisi dan peraturan.

m. Robust legal framework: Bank sentral harus memiliki otoritas yang jelas atas pengeluaran CBDC.

n. Standards: Sistem CBDC harus mematuhi standar regulasi yang sesuai, misalnya pihak swasta yang menawarkan transfer CBDC harus memenuhi standar peraturan dan kehati-hatian yang setara dengan perusahaan yang menawarkan layanan serupa untuk uang tunai.

Sejauh ini ada beberapa jenis desain CBDC yang dapat diimplementasikan, tergantung dari model, teknologi database yang mendasarinya, tingkat privasi yang tersedia, batasan jumlah, dan suku bunga. Jenis-jenis desain yang telah ada ini memiliki pengaruh atas satu sama lain dan bekerja sama untuk menciptakan sistem yang berfungsi dengan lancar. Mengingat penelitian terkait CBDC yang masih relatif baru, belum banyak penelitian, penerapan, maupun pengujiannya dalam skala besar. Akibatnya, tidak banyak pilihan untuk membandingkan desain-desain tersebut. Observasi lebih jauh terhadap cara kerja sistem dan peran swasta maupun publik masih sangat diperlukan.

Secara garis besar, tipe desain yang diperlukan untuk menggunakan CBDC dibagi menjadi tiga, yaitu desain instrumen, desain ledger, dan desain insentif. Sebagaimana dijelaskan berikut ini: ${ }^{19}$

a. Desain instrumen merujuk pada "bentuk" CBDC yang digunakan, apakah dengan bunga (interest bearing) atau dengan limit kepemilikan individu. Secara teoritis, menggunakan desain CBDC dengan bunga dapat berperan dalam mengendalikan permintaan CBDC dan suku bunganya. Dengan demikian, atribut CBDC yang digunakan dalam desain ini akan seperti deposit, bukan uang tunai. Kekurangan dari desain ini adalah kemungkinan disintermediasi yang semakin cepat, dimana nasabah memilih untuk menarik deposit dari bank untuk digantikan dengan deposit CBDC di bank sentral. Melimitasi jumlah kepemilikan individu dapat mengurangi risiko tersebut, tetapi juga dengan mengurangi keefektifan bunga CBDC. Alternatif lain dapat berupa membuat

${ }^{19}$ Bank for International Settlements I, Op.Cit.[12-13]. 
tingkatan-tingkatan suku bunga berdasarkan jumlah deposit yang dimiliki. Bank sentral memiliki pengalaman terkait sistem remunerasi bertingkat. Sistem ini dapat diterapkan ke CBDC beratribut deposit dan dapat mengatasi krisis struktural dan keuangan terkait masalah disintermediasi bank tanpa mengekspos pihak yang menggunakan CBDC untuk tujuan pembayaran. ${ }^{20}$ Sisi negatifnya, limitasi dan tingkatan bunga ini dapat menimbulkan kompleksitas dan tantangan kalibrasi bagi bank sentral dan pengguna CBDC.

b. Tipe desain selanjutnya adalah desain ledger. Dalam penggunaan CBDC, yang dimaksud dengan pembayaran adalah transfer kewajiban bank sentral yang dicatat dalam ledger (buku besar). Dengan kata lain, desain ini merujuk pada sistem yang digunakan dan untuk mencatat CBDC tersebut. Ada 5 (lima) faktor yang harus diperhatikan dalam mendesain ledger CBDC, yaitu struktur, otentikasi pembayaran, fungsionalitas, akses, dan pengaturan. Struktur ledger dapat berupa sentralisasi, desentralisasi, atau kombinasi. Struktur sentralisasi memerlukan perantara untuk mengelola dan mentransfer, sehingga keamanan lebih terjamin. Di sisi lain, struktur desentralisasi dapat memudahkan pembayaran peer-to-peer $(\mathrm{P} 2 \mathrm{P})$ dan offline, dengan risiko keamanan karena memerlukan teknologi sentralisasi ledger seperti blockchain.

Alternatif lain adalah dengan struktur kombinasi antara sentralisasi dan desentralisasi, misalkan ledger sentralisasi hanya mencatat jumlah CBDC yang dikeluarkan bank sentral, sedangkan jumlah saldo individu disimpan dalam kartu atau smartphone pengguna. Namun, mengembangkan struktur kombinasi ini dapat menghasilkan kompleksitas yang menimbulkan beban yang signifikan pada fungsi sistem.

Dalam laman Frequently Asked Question / FAQ terkait CBDC di website Bank Indonesia, Bank Indonesia menyatakan bahwa dari sisi Bank Sentral, pengelolaan CBDC akan lebih mudah karena secara terdesentralisasi. ${ }^{21}$ Dari laman

\footnotetext{
${ }^{20}$ John Kiff, et.al., Loc.Cit.

${ }^{21}$ Bank Indonesia, 'Rupiah Digital / Central Bank Digital Currency (CBDC)' (Bank Indonesia, 2021) <https://bicara.bi.go.id/knowledgebase/article/KA-01038> dikunjungi pada 29-04-2021.
} 
tersebut, Bank Indonesia memilih struktur desentralisasi dibandingkan dengan struktur sentralisasi atau kombinasi. Struktur ini memiliki beberapa kelebihan dari struktur lainnya, seperti berkurangnya biaya dengan menghilangkan verifikasi dari pihak ketiga, privasi saat transaksi, dan teknologi yang transparan. Pada saat skripsi ini disusun, Bank Indonesia masih mempertimbangkan berbagai faktor untuk penerapan CBDC. Salah satu pertimbangan untuk menerapkannya adalah pilihan teknologinya. ${ }^{22}$

Proses otentikasi pembayaran, seperti berbasis identitas, token, atau multifaktor, akan mengarahkan struktur data yang mendasari sistem CBDC dan menentukan cara integrasi dengan sistem lainnya (misalnya untuk verifikasi identitas digital sebagai bagian dari know-your-customer (KYC) atau dengan persyaratan pemantauan transaksi). Otentikasi pembayaran ini juga berfungsi sebagai jaminan tingkat privasi untuk pengguna. Jenis transaksi yang berbeda dapat juga memerlukan metode otentikasi yang berbeda, misalkan pembayaran dengan nilai yang lebih rendah menggunakan menggunakan metode yang lebih mudah, sedangkan pembayaran dengan nilai yang tinggi memerlukan syaratsyarat tambahan.

Penerbitan CBDC melalui sistem ledger dengan metode sentralisasi dan desentralisasi memberikan panduan terkait pencatatan pada penerbitan CBDC. Fungsi ledger CBDC hanya sebagai catatan kewajiban bank sentral atau dengan fungsi tambahan, seperti dapat menyinkronisasikan pembayaran. Fungsi-fungsi tambahan ini dapat membantu mendorong penerapan CBDC, tapi juga meningkatkan biaya.

Persyaratan akses, misalkan untuk menetapkan pihak mana saja yang berwenang untuk membaca dan menulis ledger, akan memengaruhi keselamatan dan efisiensi seluruh sistem. Perlu ada keseimbangan antara mendorong keragaman dan persaingan dalam sistem sambal mempertahankan standar regulasi yang memadai dari pihak swasta.

\footnotetext{
${ }^{22}$ Bidara Pink, 'BI akan minta desain acuan Central Bank Digital Currency di pertemuan G20' (Kontan, 2021) <https://nasional.kontan.co.id/news/bi-akan-minta-desain-acuan-centralbank-digital-currency-di-pertemuan-g20>, dikunjungi pada 24-06-2021.
} 
Faktor terakhir yang harus dipikirkan dalam mendesain ledger adalah pengaturannya. Sistem CBDC akan membutuhkan susunan peraturan terkait peran dan tanggung jawab operator, peserta, penyedia layanan, dan pihak-pihak berkepentingan lainnya. Selain aturan yang berisi peran dan tanggung jawab, pengaturan lainnya juga perlu dipertimbangkan, seperti limitasi diskresi bank sentral untuk memodifikasi sistem dan pembagian data dan privasi.

Mengeluarkan CBDC membutuhkan biaya, belum lagi untuk biaya operasional, sama seperti untuk produksi uang tunai. Memutuskan pihak yang harus berperan dalam pembiayaan akan berimplikasi pada efisiensi sistem, persaingan, inovasi, dan inklusivitas. ${ }^{23}$ Menarik biaya secara langsung dari pengguna merupakan salah satu pilihan yang paling transparan, akan tetapi dapat mengurangi minat masyarakat untuk menggunakan CBDC. Bank sentral dapat menggunakan seigniorage (keuntungan bank dari perbedaan antara nilai nominal uang dan biaya produksinya) yang diperoleh untuk mengurangi atau bahkan menutupi kebutuhan biaya, sedangkan membebankan biaya pada penyedia layanan berarti para penyedia layanan harus memiliki model bisnis yang layak untuk menutupi pengeluaran. ${ }^{24}$

\section{Risiko Pada Digital Currency}

Perkembangan mata uang digital berdasarkan penggunaan ledger menimbulkan sejumlah masalah, baik terkait kebijakan bagi bank sentral dan otoritas publik lainnya maupun terhadap perekonomian negara. Bank sentral harus mempertimbangkan tata kelola, organisasi internal, serta pro dan kontra dari penerbitan CBDC. Baik dewan maupun staf tingkat operasional harus memahami jelas terkait masalah utama dalam pertimbangan awal dan implementasi setelah keputusan untuk menerbitkan CBDC dibuat. Masalah-masalah ini dapat termasuk:25

a. Tujuan CBDC;

b. Konsekuensi kebijakan (misalnya terkait posisi CBDC dalam kebijakan pemerintah atau koeksistensi mata uang fisik dan digital serta pengaruhnya

\footnotetext{
${ }^{23}$ Bank for International Settlements I, Op.Cit.[13].

${ }^{24}$ ibid.

${ }^{25}$ John Kiff, et.al., Loc.Cit.
} 
terhadap pengelolaan likuiditas dan mata uang tunai operasional);

c. Persyaratan teknis;

d. Efek pada organisasi internal (seperti pengembangan kapasitas dan keahlian), manajemen risiko (risiko keterlibatan / pengadaan dan outsourcing pihak ketiga, keamanan dunia maya, dan risiko operasional, hukum, dan reputasi lainnya), pengumpulan dan pengelolaan data; dan

e. Persyaratan transparansi dan akuntabilitas (misalnya terkait temuan audit internal, mekanisme akuntansi, dan komunikasi internal dan eksternal).

Dari sisi finansial, mengeluarkan CBDC memiliki risiko mempengaruhi transmisi kebijakan moneter, misalnya dengan mengubah jumlah permintaan dan komposisi uang kartal yang tidak bisa diprediksi atau mengubah sensitivitas permintaan uang terhadap perubahan suku bunga. Dampak ini bisa saja tidak signifikan jika desain CBDC yang digunakan memadai. Transmisi kebijakan moneter dapat menguat jika CBDC meningkatkan inklusi keuangan dan mengenalkan berbagai pihak kepada instrumen keuangan yang sensitif terhadap suku bunga. CBDC juga memfasilitasi pengelolaan mata uang yang lebih aktif, mengarahkan pada pergerakan nilai tukar yang lebih kuat untuk perubahan nilai pasar tertentu. Transmisi pinjaman bank, dimana kebijakan moneter mempengaruhi kelayakan kredit bank dan biaya pendanaan, juga dapat dipertahankan jika bank sentral menyediakan pendanaan yang stabil dengan mendaur ulang deposit kembali ke sistem perbankan. ${ }^{26}$

Juga tergantung dengan desain yang digunakan, $\mathrm{CBDC}$ dapat mempengaruhi stabilitas keuangan dan intermediasi perbankan jika disaingkan dengan deposit di bank komersial. Sejauh mana persaingan ini dapat terjadi akan tergantung kepada suku bunga. Bank yang memiliki simpanan ritel yang lebih besar akan bersaing dengan CBDC, terutama yang berbunga, dan mungkin harus menaikkan suku bunga deposit agar tetap kompetitif. Suku bunga deposit yang lebih tinggi akan mengurangi margin bunga. Untuk melawannya, bank dapat mencoba menaikkan suku bunga pinjaman, tetapi dengan risiko berkurangnya jumlah permintaan pinjaman. ${ }^{27}$

\footnotetext{
${ }^{26}$ ibid. [15].
}

${ }^{27}$ ibid. 
Disintermediasi juga mungkin terjadi akibat dari penggunaan sistem CBDC itu sendiri. Dengan sistem desentralisasi, tidak adanya perantara untuk menggunakan CBDC dapat menghilangkan minat pengguna terhadap bank komersial. Dengan CBDC, pengguna tidak memerlukan bank komersial untuk melakukan transfer karena adanya sistem P2P tanpa perantara. Ada kemungkinan karena fasilitas ini pengguna akan lebih memilih menggunakan CBDC dan menarik depositnya di bank komersial untuk selanjutnya dikonversikan menjadi CBDC. Hal ini dapat menimbulkan bank run / rush money dan mengakibatkan bank pailit. ${ }^{28}$

Sisi positif dari penggunaan CBDC adalah adanya kesempatan untuk kebijakan moneter menembus batas bawah efektif dan membantu menjaga efektivitas kebijakan moneter dengan mengurangi insentif untuk mengadopsi alat pembayaran alternatif. Penggunaan alat pembayaran yang tidak termasuk dalam mata uang domestik (termasuk mata uang asing dan cryptocurrency) dapat membahayakan kemampuan bank sentral untuk mencapai tujuan kebijakan moneternya saat ini. ${ }^{29}$

Disisi biaya kebijakan moneter, CBDC dapat menyebabkan besarnya pengurangan saldo cadangan (deposito bank komersial dan lembaga penyimpanan lainnya) ketika ada perubahan kualitas, menaikkan suku bunga pasar uang dan berpotensi mendestabilisasi pasar keuangan. Untuk mempersiapkan perubahan demikian dan untuk mengakomodasi potensi permintaan CBDC, bank sentral harus mempertahankan neraca yang jauh lebih besar, mungkin lebih dari sepertiga dari GDP. ${ }^{30}$

Sedangkan dari sisi operasional dan legal, pada dasarnya CBDC adalah suatu mata uang digital, yang berarti dalam prosesnya menggunakan teknologi. Cybersecurity menjadi salah satu faktor paling penting dalam pembuatan dan pengoperasian CBDC. Dengan berkembangnya teknologi, berkembang pula ancaman-ancaman di dalamnya. Tidak sedikit ancaman keamanan siber canggih

\footnotetext{
${ }^{28}$ Bank for International Settlements I, Op.Cit.[8].

${ }^{29}$ Mohammad Davoodalhosseini, et.al., 'CBDC and Monetary Policy', Bank of Canada Staff Analytical Note (2020).

${ }^{30}$ Bill Nelson, 'The Benefits and Costs of a Central Bank Digital Currency for Monetary Policy’ (BPI, 2021) < https://bpi.com/the-benefits-and-costs-of-a-central-bank-digital-currency-formonetary-policy/>, dikunjungi pada 28-06-2021.
} 
yang selalu berubah muncul tiap harinya. Pihak-pihak tidak bertanggung jawab dapat membobol keamanan siber CBDC jika sistem keamanan yang digunakan belum mutakhir. Cybersecurity merupakan risiko yang selalu ada dan signifikan terhadap segala jenis infrastruktur pembayaran. Ini menekankan betapa pentingnya bagi bank sentral untuk merancang, membangun, dan menjalankan ekosistem CBDC yang aman dan tangguh secara keseluruhan di seluruh komponen dan integrasi sistem. Sebagai infrastruktur yang akan berperan penting, keamanan dan ketahanan CBDC setidaknya harus mirip dengan sistem pembayaran saat ini dengan layanan yang beroperasi $24 / 7 .{ }^{31}$

Risiko legal lainnya terdapat dalam perlindungan konsumen terkait sulitnya memproyeksikan nilai mata uang digital di masa depan. Umumnya nilai mata uang digital didenominasikan dalam unit nilainya sendiri, tidak memiliki nilai intrinsik, bergantung pada persepsi pengguna tentang nilai dan harga, tidak terikat pada mata uang negara, dan bukan merupakan kewajiban siapapun. ${ }^{32}$ Dengan demikian, nilai mata uang digital hanya berdasarkan ekspektasi pengguna bahwa mereka dapat menukarnya dengan barang dan jasa atau mata uang negara lain di kemudian hari. Hal ini tentunya sangat tidak stabil. Ekspektasi setiap orang berbeda-beda dan dapat dengan mudah berubah dalam waktu singkat, menyebabkan volatilitas dan risiko kerugian yang lebih besar daripada valuta asing pada umumnya. Tidak seperti mata uang digital pada umumnya, CBDC secara resmi dikeluarkan oleh bank sentral negara. Nilai CBDC terhadap mata uang lain akan lebih stabil karena tidak bergantung pada persepsi atau ekspektasi pengguna, seperti layaknya mata uang fisik. Faktor ekonomi yang dapat mempengaruhi adalah tingkat inflasi, tingkat suku bunga, jumlah uang beredar, aliran modal yang masuk maupun keluar, posisi neraca pembayaran internasional Indonesia serta kebijakan-kebijakan moneter yang dijalankan pemerintah. ${ }^{33}$

\footnotetext{
${ }^{31}$ Bank for International Settlements I, Op.cit, [14].

${ }^{32}$ Bank for International Settlements, 'Committee on Payments and Market Infrastructures: Digital currencies’ (BIS Papers, 2015) (selanjutnya disingkat Bank for International Settlements II).[14].

${ }^{33}$ Samsul Arifin \& Shany Mayasya, 'Faktor - Faktor Yang Mempengaruhi Nilai Tukar Rupiah Terhadap Dolar Amerika Serikat' (2018) 8 Jurnal Ekonomi-Qu.[83].
} 


\section{Fungsi dan Wewenang Bank Sentral}

Sesuai dengan UU BI, Bank Indonesia sebagai bank sentral bertujuan untuk mencapai dan memelihara kestabilan rupiah. Untuk mencapai tujuan tersebut, Bank Indonesia memiliki tugas dan fungsi untuk menetapkan dan melaksanakan kebijakan moneter, mengatur dan menjaga kelancaran sistem pembayaran, serta mengatur dan mengawasi Bank. Fungsi moneter dan sistem pembayaran inilah yang akan berhubungan dengan implementasi CBDC. Pasal 10 UU BI menyebutkan wewenang Bank Indonesia dalam rangka menetapkan dan melaksanakan kebijakan moneter sebagai berikut:

1. Menetapkan sasaran-sasaran moneter dengan memerhatikan sasaran lalu lintas yang ditetapkannya;

2. Melaksanakan pengendalian moneter dengan menggunakan cara-cara yang termasuk, tetapi tidak terbatas pada:

a. Operasi pasar terbuka di pasar uang baik rupiah maupun valuta asing;

b. Penetapan tingkat diskonto;

c. Penetapan cadangan wajib minimum;

d. Pengaturan kredit atau pembiayaan.

Wewenang Bank Indonesia untuk pemenuhan fungsi moneter tersebut dituangkan dalam PBI Moneter. Bank Indonesia kemudian memiliki tugas dan wewenang untuk melakukan pengawasan moneter dalam rangka memastikan kepatuhan terhadap ketentuan di bidang moneter dan untuk mencegah dan mengurangi risiko di bidang moneter. Pengawasan ini dilakukan secara tidak langsung, seperti dengan mewajibkan penyediaan data, informasi, dan / atau keterangan yang diperlukan dari pihak di bawah pengawasan, maupun dengan pemeriksaan langsung.

Sedangkan dalam menjalankan fungsinya untuk mengatur dan menjaga kelancaran sistem pembayaran, wewenang Bank Indonesia dalam pasal 15 UU BI adalah:

1. Melaksanakan dan memberikan persetujuan dan izin atas penyelenggaraan jasa sistem pembayaran;

2. Mewajibkan penyelenggara jasa sistem pembayaran untuk menyampaikan laporan kegiatannya; 
3. Menentukan dan menetapkan penggunaan alat pembayaran.

Wewenang Bank Indonesia untuk pemenuhan fungsi sistem pembayaran tersebut kemudian diperjelas dalam PBI Sistem Pembayaran. Pasal 7 PBI Sistem Pembayaran memperluas wewenang dalam pasal 15 UU BI menjadi:

1. Perumusan, penetapan, dan komunikasi kebijakan di bidang Sistem Pembayaran;

2. Penerbitan peraturan di bidang Sistem Pembayaran;

3. Penetapan akses ke penyelenggaraan Sistem Pembayaran;

4. Persetujuan dan pelaporan terhadap pengembangan aktivitas, pengembangan produk, dan/atau kerja sama dalam penyelenggaraan Sistem Pembayaran;

5. Penyelenggaraan infrastruktur Sistem Pembayaran;

6. Pengawasan dan pengenaan sanksi;

7. Pengelolaan data dan/atau informasi terkait Sistem Pembayaran;

8. Kewenangan lain di bidang Sistem Pembayaran yang ditetapkan Bank Indonesia.

Kewenangan Bank Indonesia lainnya terkait dengan sistem pembayaran adalah menetapkan penggunaan alat pembayaran, agar alat pembayaran yang digunakan dalam masyarakat memenuhi persyaratan keamanan bagi pengguna. Termasuk dalam wewenang ini adalah membatasi menggunakan alat pembayaran tertentu dalam rangka prinsip kehati-hatian. ${ }^{34}$

\section{Koordinasi Cybersecurity pada Financial Stability di Indonesia}

Cybersecurity adalah salah satu risiko besar yang dihadapi seiring dengan perkembangan fintech. Bank sentral bertanggung jawab untuk menetapkan kerangka ketahanan siber dan memastikan bahwa cybersecurity dikelola secara efektif dengan menetapkan tingkat toleransi terhadap risiko siber. Peraturan terkait cybersecurity di Indonesia yang masih berlaku adalah UU Nomor 11 Tahun 2008 jo. UU Nomor 19 Tahun 2016 tentang Informasi dan Transaksi Elektronik (selanjutnya disebut sebagai UU ITE). UU ITE memberikan perlindungan hukum untuk konten sistem elektronik dan transaksi elektronik. Akan tetapi, UU ini tidak mencakup aspek penting keamanan siber, seperti infrastruktur informasi

\footnotetext{
${ }^{34}$ Nanda Patimbano, 'Tugas Bank Indonesia Sebagai Bank Sentral di Indonesia Menurut Undang-Undang Nomor 23 Tahun 1999 Juncto Undang-Undang Nomor 6 Tahun 2009’ (2016) IV Lex Administratum.[78].
} 
dan jaringan, dan sumber daya manusia dengan keahlian di bidang keamanan siber. ${ }^{35}$ Sebagai salah satu bentuk komitmen Indonesia terhadap keamanan siber, adanya rencana penyusunan Rancangan Undang-undang (RUU) Keamanan dan Ketahanan Siber (KKS) dimaksudkan untuk melengkapi kekurangan dalam UU ITE. Mengingat ancaman siber nyata terjadi dalam perspektif keamanan nasional yang modern, dimana negara harus berupaya mewujudkan keamanan tersebut mulai dari tahap pencegahan sampai pada tahap pemulihan termasuk dalam konteks keamanan siber sebagai sub-sistem dari keamanan nasional, RUU KKS memiliki peran yang penting. Dalam kenyataannya, masih terdapat banyak tantangan yang belum dapat diatasi dengan peraturan perundang-undangan yang ada, misalnya belum terdapat keseragaman tata kelola keamanan siber, belum berfungsinya pelayanan keamanan siber yang efektif, dan belum optimalnya pemanfaatan keahlian keamanan siber dalam proses penegakan hukum. Untuk itu, dalam mewujudkan penyelenggaraan keamanan siber nasional yang efektif yang dapat mengatasi berbagai tantangan serta untuk menjamin bahwa penyelenggaraan keamanan siber tersebut sesuai dengan kepentingan perlindungan hak asasi manusia, maka kehadiran Undang-Undang Keamanan dan Ketahanan Siber menjadi sangat penting.

Dikaitkan dengan status Bank Indonesia sebagai lembaga negara yang independen berdasarkan Pasal 4 ayat (2) UU BI sebagaimana telah diubah beberapa kali (terakhir dengan UU No. 6 Tahun 2009), maka penyelenggaraan keamanan dan ketahanan siber dalam lingkup internal Bank Indonesia masuk dalam ruang lingkup pengaturan penyelenggaraan keamanan dan ketahanan siber menurut RUU KSS.

Merujuk pada definisi siber dalam RUU KSS, terdapat sarana interaksi antara manusia dengan teknologi informasi, komputerisasi, jaringan computer, kriptografi, dan / atau kecerdasan buatan (AI) yang digunakan oleh Bank Indonesia dalam konteks pelaksanaan tugas dan wewenang Bank Indonesia sebagaimana diamanatkan oleh UU BI. Dari sisi pelaksanaan tugas pokok, Bank Indonesia

${ }^{35}$ Noor Halimah Anjani, 'Ringkasan Kebijakan No. 9: Perlindungan Keamanan Siber di Indonesia’ Center for Indonesian Policy Studies (2021). 
memiliki sarana siber yang merupakan bagian dari Financial Market Infrastructure (FMI) di Indonesia. Desain FMI tersusun dari beberapa fungsi FMI, antara lain payment system (PS), central securities depositories (CSD), securities settlement system (SSS), central counterparties (CCP), dan trade repositories (TR), masingmasing fungsi FMI tersebut memiliki hubungan satu dengan yang lain. ${ }^{36}$

Di dalam proses dan prosedur pelaksanaan perbankan di Bank Indonesia, fungsi-fungsi tersebut dilaksanakan melalui beberapa system meliputi: fungsi PS melalui Bank Indonesia Real Time Gross Settlement (BI-RTGS) dan Sistem Kliring Nasional Bank Indonesia (SKNBI); fungsi SSS dan CSD melalui Bank Indonesia Scripless Securities Settlement System (BI-SSSS), dan fungsi trading system melalui Bank Indonesia-Electronic Trading Platform (BI-ETP). Fungsi-fungsi ini berkaitan satu dengan lainnya termasuk fungsi FMI yang berada diluar Bank Indonesia yang dioperasikan oleh pihak lain yang memiliki kewenangan dalam mengoperasikan FMI, seperti fungsi CCP oleh Kliring Penjaminan Efek Indonesia (KPEI) dan fungsi SSS dan CSD oleh custodian Sentral Efek Indonesia (KSEI).

Dalam menyelenggarakan sistem keamanan siber tentu perlu adanya kerjasama dan koordinasi dari segenap pihak untuk memastikan sistem kontrol cyber risk management dapat berjalan secara optimal. Sehingga dalam hal ini, pemerintah dapat segera mengambil keputusan yang cepat dan tepat atas adanya laporan serangan siber yang terjadi.

Manajemen risiko pada dasarnya merupakan elemen fundamental dari sebuah strategi. Dengan melakukan manajemen risiko, pemerintah dapat membuat perhitungan anggaran biaya yang diperlukan dalam penanggulangan serangan siber, sebab biaya yang harus dikeluarkan dalam melakukan pengamanan kerahasiaan informasi dan data sebuah negara tidaklah sedikit. Dengan demikian, manajemen risiko yang dibuat dapat membuat sebuah strategi yang lebih terjangkau dalam menghadapi berbagai ancaman siber.

\footnotetext{
${ }^{36}$ Bank Indonesia, 'Infrastruktur Pasar Keuangan' (Bank Indonesia, 2021) <https://www. bi.go.id/id/fungsi-utama/sistem-pembayaran/Infrastruktur-Pasar-Keuangan/Default.aspx>, dikunjungi pada 24-06-2021.
} 
Pada dasarnya, terdapat beberapa aspek terkait keamanan informasi yang harus diperhatikan dalam menyusun kebijakan dan kerangka hukum cybersecurity. BSSN dalam buku Panduan Pengaturan Cybersecurity di Indonesia menyatakan adanya 5 (lima) aspek keamanan informasi yang harus diperhatikan, antara lain yaitu Confidentiality, Integrity, Availability, Authentication, dan Non Repudiation ${ }^{37}$ Confidentiality adalah bahwa informasi tidak tersedia atau diungkapkan kepada individu, entitas, atau proses yang tidak sah. ${ }^{38}$ Artinya, bahwa sistem informasi dalam hal ini harus menjamin dan memastikan bahwa informasi hanya dapat diakses dan digunakan oleh orang yang mempunyai wewenang sekaligus menjamin bahwa informasi yang dikirim, diterima, dan disimpan benar-benar terjamin kerahasiannya. Informasi rahasia yang terakses terhadap pihak-pihak yang tidak berwenang tentu memiliki konsekuensi yang sangat serius terhadap sistem keamanan nasional. Integrity adalah tindakan menjaga keakuratan dan kelengkapan asset. Secara lebih luas, prinsip integrity berarti bahwa informasi yang diterima tidak diubah, dimanipulasi, dimodifikasi maupun dihilangkan tanpa izin dari pihak berwenang, serta menjaga keakuratan dan kesempurnaan informasi dan prosesnya. Adapun Availibility berarti bahwa informasi akan tersedia ketika dibutuhkan, serta memastikan pihak yang berwenang dapat menggunakan informasi yang dibutuhkan tanpa ada gangguan atau interupsi terhadap sistem dan jaringan. Authentication berarti bahwa sistem dapat membuktikan bahwa pengguna memiliki hak klaim terhadap informasi yang diakses. Adapun Non repudiation berarti bahwa prinsip yang memastikan suatu aksi atau transaksi menjadi tidak dapat dibantah. Secara lebih rinci, ruang lingkup prinsip non repudiation adalah meliputi; 1) non repudiation pada tanda terima, artinya bahwa melalui mekanisme ini pengirim dapat membuktikan bahwa pesan telah dikirimkan kepada orang yang tepat. Hal tersebut dimaksudkan untuk menghindari adanya situasi dimana pihak pengirim telah mengirimkan pesan atau informasi namun tidak dapat membuktikan bahwa

${ }^{37}$ BSSN, Pengaturan Cybersecurity di Indonesia (2020).

${ }^{38}$ Badan Standarisasi Nasional, ISO IEC 27001 Teknologi Informasi-Teknik KeamananSistem Manajemen Keamanan Informasi (2009). 
pihak penerima telah mendapatkannya. 2) non repudiation bagi pengirim, bahwa melalui mekanisme tersebut diharapkan dapat membuktikan bahwa suatu pesan datang dari orang yang tepat. Hal tersebut dimaksudkan untuk menghindari situasi dimana pesan yang diterima kemudian dibantah oleh pengirim. 3) non repudiation terhadap waktu, yaitu prinsip yang mendefinisikan waktu ketika suatu pesan atau informasi dikirimkan.

Sebagai konsekuensi dianutnya negara hukum oleh Indonesia, maka segala kegiatan yang berkaitan dengan penyelenggaraan negara haruslah didasarkan pada hukum. Selain itu, dalam rangka menjalankan tata kelola pemerintahan yang baik (good governance), maka diperlukan adanya kebijakan sebagai landasan hukum. Kebijakan tersebut juga diperlukan dalam rangka menjaga arah dari kegiatankegiatan pengembangan pembangunan dan penerapan pertahanan cyber agar selalu sesuai dengan peraturan perundang-undangan. Kebijakan yang dimaksud dalam hal ini yang dimaksud adalah sebagai acuan bagi seluruh kegiatan pertahanan dan cybersecurity yang diwujudkan baik dalam bentuk peraturan, pedoman, petunjuk teknis, dan bentuk kebijakan-kebijakan lainnya yang meliputi aspek pengembangan kelembagaan, persiapan, infrastruktur dan teknologi, persiapan SDM, hingga pengaturan mengenai fungsi, peran, dan wewenang dalam kerangka pertahanan cyber (cyberresilience). Pada tingkatan operasional, kebijakan berbentuk pedoman, petunjuk pelaksanaan, petunjuk teknis yang dijadikan acuan utama dalam cybersecurity.

Bidang keamanan siber merupakan salah satu bidang pemerintahan yang perlu didorong dan diperkuat sebagai upaya meningkatkan pertumbuhan ekonomi nasional dan mewujudkan keamanan nasional. Berdasarkan Pasal 2 Peraturan Presiden Nomor 53 Tahun 2017 tentang Badan Siber dan Sandi Negara, diatur bahwa BSSN mempunyai tugas melaksanakan keamanan siber secara efektif dan efisien dengan memanfaatkan, mengembangkan, dan mengonsolidasikan semua unsur yang terkait dengan keamanan siber, selaras dengan hal tersebut dalam hal penguatan ekonomi nasional, maka koordinasi di sektor jasa keuangan yang harus diintegrasikan dengan peran Bank Indonesia dan Otoritas Jasa Keuangan. 
Hal tersebut karena adanya kekhususan pada sektor jasa keuangan yang memiliki karakteristik tersendiri dengan tingkat rentabilitas yang tinggi. Rentabilitas yang tinggi pada sektor jasa keuangan tersebut menjadi unsur yang penting untuk menerapkan urgensi pengaturan dan tingkat koordinasi oleh BSSN, yang dalam hal ini pelaksanaan supervisi secara koordinatif harus dilaksanakan secara lex spesialis kepada bank sentral, sebagai amanat Pasal 8 UU BI, bahwa Bank Indonesia memiliki tugas untuk menetapkan dan melaksanakan kebijakan moneter, dan bahwa dalam rangka menetapkan kebijakan moneter tersebut BI akan melakukan pengawasan bersama dengan OJK untuk melakukan fungsi supervisi di bidang moneter. Hal ini diperlukan guna mendukung terwujudnya perekonomian nasional sejalan dengan tantangan perkembangan dan pembangunan ekonomi yang semakin kompleks, sistem keuangan yang semakin maju serta perekonomian internasional yang semakin kompetitif dan terintegrasi, kebijakan moneter harus dititikberatkan pada upaya untuk memelihara stabilitas nilai rupiah dan bahwa untuk menetapkan dan melaksanakan kebijakan moneter yang efektif dan efisien diperlukan sistem keuangan yang sehat, transparan, terpercaya, dan dapat dipertanggungjawabkan yang didukung oleh sistem pembayaran yang lancar, cepat, tepat, dan aman, serta pengaturan dan pengawasan bank yang memenuhi prinsip kehati-hatian.

Bank Indonesia sebagai bank sentral yang bertugas untuk menetapkan dan melaksanakan kebijakan moneter, mengatur dan menjaga kelancaran sistem pembayaran, dan melakukan pengawasan secara makro terhadap sektor jasa keuangan, maka BI melakukan pengaturan-pengaturan terkait penggunaan teknologi dalam kegiatan sektor jasa keuangan, diantaranya adalah sebagai berikut:

1. Undang-Undang Nomor 11 Tahun 2008 tentang Informasi dan Transaksi Elektronik;

2. Undang-Undang Nomor 6 Tahun 2009 tentang Penetapan Perubahan Kedua atas Peraturan Pemerintah Pengganti Undang-Undang Nomor 2 Tahun 2008 tentang Perubahan Undang-Undang Nomor 23 Tahun 1999 tentang Bank Indonesia;

3. Undang-Undang Nomor 23 Tahun 1999 tentang Bank Indonesia sebagaimana telah diubah terakhir dengan Undang-Undang Nomor 6 Tahun 2009;

4. Undang-Undang Nomor 7 Tahun 1992 tentang Perbankan sebagaimana telah diubah dengan Undang- Undang Nomor 10 Tahun 1998;

5. Undang-Undang Nomor 8 Tahun 1999 tentang Perlindungan Konsumen;

6. Peraturan Pemerintah Nomor 82 tahun 2012 tentang Penyelenggaraan Sistem dan Transaksi Elektronik; 
7. Peraturan Bank Indonesia Nomor $14 / 2 / \mathrm{PBI} / 2012$ Perubahan atas Peraturan Bank Indonesia Nomor 11/11/PBI/2009 tentang Penyelenggaraan Kegiatan Alat Pembayaran dengan Menggunakan Kartu;

8. Peraturan Bank Indonesia No. 9/15/PBI/2007 Penerapan Manajemen Risiko Dalam Penggunaan Teknologi Informasi oleh Bank Umum dan Lampiran;

9. Peraturan Bank Indonesia No.11/12/PBI/2009 tentang Uang Elektronik (Electronic Money);

10. Surat Edaran Bank Indonesia No.16/11/DKSP tanggal 22 Juli 2014 perihal Penyelenggaraan Uang Elektronik (Electronic Money);

11. Surat Edaran Bank Indonesia No.15/13/DASP tanggal 12 April 2013 perihal Laporan Penyelenggaraan Kegiatan Alat Pembayaran dengan Menggunakan Kartu dan Uang Elektronik (Electronic Money) oleh Bank Perkreditan Rakyat dan Lembaga Selain Bank;

12. Peraturan Bank Indonesia No.19/12/PBI/2017 tentang Penyelenggaraan Teknologi Finansial; dan

13. Peraturan Bank Indonesia Nomor 20/6/PBI/2018 tentang Uang Elektronik.

Ketentuan-ketentuan tersebut apabila dikaitkan dengan kewenangan Bank Indonesia dalam sistem pembayaran mengenai ketahanan sibernya maka kedepannya perlu dilakukan pengaturan yang lebih komprehensif, bukan hanya pengaturan intern terkait Bank Indonesia sebagai penyelenggara, namun perlu diberikan kewenangan lebih luar Bank Indonesia sebagai regulator, agar fungsi bank sentral sebagai pengawas moneter dapat lebih tercapai. Namun, yang perlu diperhatikan, dalam hal ini yaitu apabila Bank Indonesia mengatur dirinya sendiri sebagai penyelenggara, maka harus ada pihak ketiga yang berperan sebagai pengawas. Di sinilah fungsi koordinatif BSSN akan menjadi substansial. Fungsi koordinatif tersebut akan menjadi perwujudan fungsi good governance antara instansi pengawasan cybersecurity di sistem keuangan.

Untuk memastikan ketahanan, bank sentral dapat berkoordinasi dengan pihak ketiga yang ahli dalam bidangnya. Pihak ketiga tersebut harus secara teratur berkoordinasi dengan bank sentral dan menginformasikan riwayat risiko siber untuk memastikan bahwa tingkat risiko tersebut tetap konsisten dengan toleransi yang telah ditetapkan. Sebagai bagian dari tanggung jawab ini, bank sentral juga harus mempertimbangkan bagaimana perubahan pada layanan, kebijakan, praktik, dan lanskap ancaman dapat memengaruhi riwayat risiko sibernya. Implementasi kerangka ketahanan, kebijakan, prosedur, dan kontrol yang mendukung harus 
diawasi dengan ketat. ${ }^{39}$

Penggunaan digital banking yang sekarang telah diimplementasikan di berbagai negara sebenarnya sudah memiliki berbagai langkah keamanan bagi pengguna. Bank di Arab Saudi menyediakan 2-Factor Authentication (2FA) dimana setelah pengguna berhasil login, one-time password (OTP) akan dikirim ke nomor ponsel yang sudah terdaftar dan harus dimasukkan sebelum pengguna diarahkan ke laman digital banking. ${ }^{40}$ Di Indonesia, berbagai bank juga telah mengimplementasikan 2FA untuk bertransaksi menggunakan digital banking yang mereka sediakan. Sebagai contoh, Bank Mandiri menggunakan 2FA dengan username dan password, beserta MPIN untuk bertransaksi. Transaksi melalui laman internet juga menggunakan otentikasi transaksi melalui fiture mobile app approval, yaitu approval transaksi melalui aplikasi pada ponsel. ${ }^{41}$

\section{Kewajiban Bank Sentral dalam Risiko Penerbitan CBDC}

Sebagai bank sentral, Bank Indonesia adalah satu-satunya pihak yang berhak untuk menentukan dan menetapkan alat pembayaran sah di Indonesia. Berdasarkan UU Mata Uang, proses pengelolaan Rupiah meliputi tahapan sebagai berikut:
a. Perencanaan;
b. Pencetakan;
c. Pengeluaran;
d. Pengedaran;
e. Pencabutan dan Penarikan; dan
f. Pemusnahan.

Pasal 11 ayat(3) secara eksplisit menyatakan bahwa Bank Indonesia merupakan satu-satunya lembaga yang berwenang melakukan Pengeluaran, Pengedaran, dan/ atau Pencabutan dan Penarikan Rupiah. Mengingat CBDC yang belum memiliki

\footnotetext{
${ }^{39}$ Bank for International Settlements, 'Guidance on cyber resilience for financial market infrastructures’ (BIS Papers, 2016) (selanjutnya disingkat Bank for International Settlements III). [10].

${ }^{40}$ Zafar Kazmi, Jaafar Alghazo, dan Ghazanfar Latif, 'Cyber Security Analysis of Internet Banking in Emerging Countries: User and Bank Perspectives' 4th IEEE International Conference on Engineering Technologies and Applied Sciences (ICETAS) (2017).[6].

${ }^{41}$ Bank Mandiri, 'Livin' by Mandiri - Cara Daftar \& Aktivasi' (Mandiri, 2021) < bankmandiri. co.id>, dikunjungi pada 20-06-2021.
} 
regulasi sendiri, jika mengacu pada karakteristik CBDC yang merupakan mata uang, maka pada dasarnya segala wewenang Bank Indonesia atas Rupiah berlaku pula pada CBDC karena pada dasarnya fungsi CBDC adalah sebagai mata uang layaknya Rupiah. Dengan demikian, segala risiko terkait penerbitan CBDC akan menjadi tanggung jawab dari Bank Indonesia, berbeda dengan cryptocurrency yang tidak memiliki pihak yang dapat dimintai pertanggungjawaban. Ini menjadi salah satu poin positif dalam penerbitan CBDC.

Dalam tahap perencanaan, bank sentral perlu melakukan analisis manajemen risiko yang terintegrasi untuk menilai potensi risiko sebagai pertimbangan sebelum menerbitkan CBDC. Cybersecurity yang menjadi risiko operasional, risiko strategi dan kebijakan, risiko hukum, dan berbagai risiko lainnya menjadi tanggung jawab bank sentral sepenuhnya. Perluasan mandat bank sentral juga dapat melibatkan risiko terkait dengan kebijakan di bidang lain, terutama stabilitas keuangan (pengawasan makroprudensial, pengawasan mikroprudensial, ELA/LOLR, dan resolusi). Ini juga dapat mencakup masalah yang berkaitan dengan integritas keuangan, inklusi keuangan, perlindungan konsumen, dan kemungkinan tujuan lain dari bank sentral. ${ }^{42}$ Maka dari itu bank sentral harus menerapkan transparansi atas segala kebijakan dan tindakan yang dilaksanakan. Transparansi bank sentral dalam pengembangan CBDC akan memungkinkan akuntabilitas kepada pihak-pihak yang berkepentingan, baik dari pemerintah maupun masyarakat, serta mengklarifikasi mandat dan kerangka hukum bank sentral. Sesuai dengan UU BI, prinsip akuntabilitas dari pelaksanaan tugas dan wewenang Bank Indonesia diterapkan dengan cara menyampaikan informasi langsung kepada masyarakat luas secara terbuka melalui media massa, pada setiap awal tahun, mengenai evaluasi kebijakan moneter dan penerapan sasaran-sasaran moneter untuk tahun yang akan datang. Bank Indonesia juga diwajibkan untuk menyampaikan perkembangan pelaksanaan tugas dan wewenangnya kepada DPR setiap triwulan atau sewaktu-waktu bila diminta oleh DPR. ${ }^{43}$

\footnotetext{
${ }^{42}$ John Kiff, et.al., Op.Cit.[40].

${ }^{43}$ Perry Warjiyo \& Solikin M. Juhro, 'Kebijakan Bank Sentral - Teori dan Praktik' (Rajawali Pers 2016).[483].
} 
Dalam operasionalnya, pengguna $\mathrm{CBDC}$ dapat terkena risiko tambahan dari pihak ketiga yang berpartisipasi. Pihak ketiga dapat menyimpan informasi terkait akun pengguna dan mengambil CBDC pengguna untuk digabungkan dengan aset mereka sendiri. Regulasi yang sudah ada, seperti PBI Uang Elektronik, telah mengatur terkait penanganan risiko serupa dengan mewajibkan service provider di bidang uang elektronik untuk memiliki kebijakan dan prosedur berbagai aspek seperti penerapan manajemen risiko, anti pencucian uang, perlindungan konsumen, dan keamanan sistem informasi. Jika risiko yang timbul dari pihak ketiga tersebut belum sepenuhnya teratasi dengan regulasi yang sudah ada, penggunaan CBDC bisa saja hanya terbatas pada kepemilikan dan transaksi dengan jumlah kecil untuk menghindari risiko gagal bayar pihak ketiga. Maka demikian bank sentral memiliki tanggung jawab untuk memastikan risiko ini terminimalisir sepenuhnya baik dengan mengeluarkan regulasi baru yang memadai maupun dengan menerapkan prinsip kehati-hatian.

\section{Kesimpulan}

Ada 3 (tiga) prinsip yang mendasari karakteristik CBDC, yaitu do no harm (mendukung pemenuhan tujuan publik dan tidak menghalangi tugas bank sentral untuk menjaga stabilitas moneter), coexistence (saling melengkapi dan berdampingan dengan jenis uang lainnya), dan innovation and efficiency (mendorong efisiensi sistem pembayaran dengan inovasi dan saingan). Karakteristik CBDC sendiri adalah:

1. Diterbitkan bank sentral dalam bentuk digital dengan mempertimbangkan desain instrumen, ledger, dan insentif;

2. Dapat dimiliki oleh semua orang;

3. Memiliki tingkat konversi yang sama dengan uang kertas;

4. Dapat digunakan sebagai alat pembayaran dalam pembayaran retail; dan

5. Tidak ada pihak ketiga yang memverifikasi atau melaksanakan pembayaran.

Sebagai bank sentral, Bank Indonesia bertanggung jawab atas segala risiko dalam penerbitan CBDC karena CBDC adalah mata uang yang diterbitkan dan diregulasikan oleh bank sentral. Maka dari itu Bank Indonesia perlu melakukan analisis manajemen risiko sebelum penerbitan dan menerapkan transparansi atas segala kebijakan dan tindakan yang dilaksanakan. Bank sentral juga bertanggung jawab untuk menetapkan kerangka ketahanan siber dan memastikan bahwa 
cybersecurity dikelola secara efektif. Salah satu upaya Indonesia dalammeningkatkan cybersecurity adalah rencana penyusunan RUU Keamanan dan Ketahanan Siber. Dikaitkan dengan status lembaga negara independen Bank Indonesia sesuai UU BI, penyelenggaraan keamanan dan ketahanan siber internal Bank Indonesia termasuk ruang lingkup pengaturan penyelenggaraan keamanan dan ketahanan siber menurut RUU KSS. Kedepannya perlu dilakukan pengaturan yang lebih komprehensif terkait Bank Indonesia sebagai regulator agar fungsi bank sentral sebagai pengawas moneter dapat lebih tercapai. Jika Bank Indonesia mengatur diri sendiri sebagai penyelenggara, maka harus ada pihak ketiga sebagai pengawas. Fungsi koordinatif BSSN menjadi substansial sebagai perwujudan fungsi good governance antara instansi pengawasan cybersecurity di sistem keuangan.

\section{Daftar Bacaan}

\section{Buku}

Ahmad Hasan, Mata Uang Islami (PT. Raja Grafindo Persada 2005).

Perry Warjiyo \& Solikin M. Juhro, Kebijakan Bank Sentral - Teori dan Praktik (Rajawali Pers 2016).

Peter Mahmud Marzuki, Penelitian Hukum (Kencana Prenada Media 2011).

\section{Jurnal}

Aleksi Grym, et.al., 'Central Bank Digital Currency' (2017) BoF Economics Review.

Bastian Muzbar Zams, et.al., 'Designing Central Bank Digital Currency For Indonesia: The Delphy-Analutic Network Process' (2020) 23 Bulletin of Monetary Economics and Banking 3.

Christian Barontini \& Henry Holden, 'Proceeding with caution - a survey on central bank digital currency' (2019) 101 BIS Papers.

John Kiff, et.al., 'A Survey of Research on Retail Central Bank Digital Currency' (2020) 104 IMF Working Paper 20.

Muhammad Edhie Purnawan \& Retno Ritanti, 'A Significant Effect of the Central Bank Digital Currency on the Design of Monetary Policy' (2019) 8 Jurnal Ekonomi Indonesia 1. 
Muhammad Sofyan Abidin, 'Dampak Kebijakan E-Money di Indonesia Sebagai Alat Sistem Pembayaran Baru' (2015) 3 Jurnal Akuntansi AKUNESA 2.

Nanda Patimbano, 'Tugas Bank Indonesia Sebagai Bank Sentral di Indonesia Menurut Undang-Undang Nomor 23 Tahun 1999 Juncto Undang-Undang Nomor 6 Tahun 2009' (2016) IV Lex Administratum 4.

Samsul Arifin \& Shany Mayasya, 'Faktor-Faktor Yang Mempengaruhi Nilai Tukar Rupiah Terhadap Dolar Amerika Serikat' (2018) 8 Jurnal Ekonomi-Qu 1.

\section{Laman}

Andrea Lidwina, 'Nilai Transaksi Uang Elektronik Naik 30\% pada Awal 2021', (Katadata, 2021) <https://databoks.katadata.co.id/datapublish/2021/03/04/ nilai-transaksi-uang-elektronik-naik-30-pada-awal-2021>, dikunjungi pada tanggal 26 Juli 2021.

Bank Indonesia, 'Infrastruktur Pasar Keuangan', (Bank Indonesia, 2021) <https:// www.bi.go.id/id/fungsi-utama/sistem-pembayaran/Infrastruktur-PasarKeuangan/Default.aspx>, dikunjungi pada tanggal 24 Juni 2021.

Bank Indonesia, 'Rupiah Digital / Central Bank Digital Currency (CBDC)', (Bank Indonesia, 2021) <https://bicara.bi.go.id/knowledgebase/article/KA-01038>, dikunjungi pada tanggal 29 April 2021.

Bank Indonesia, 'Sistem Pembayaran \& Pengelolaan Uang Rupiah', (Bank Indonesia, 2021) https://www.bi.go.id/id/fungsi-utama/sistem-pembayaran/ default.aspx, dikunjungi pada tanggal 26 Maret 2021.

Bill Nelson, 'The Benefits and Costs of a Central Bank Digital Currency for Monetary Policy', (BPI, 2021) <https://bpi.com/the-benefits-and-costs-of-a-central-bankdigital-currency-for-monetary-policy/>, dikunjungi pada tanggal 28 Juni 2021.

Difi Dahliana, 'Sejarah Uang', (UIN Antasari, 2021) https://doi.org/10.17605/OSF. IO/WS8JE, dikunjungi pada tanggal 30 Mei 2021.

Giri Hartono, 'BI Catat Penggunaan Uang Elektronik Tumbuh 172,85\%', (Okezone, 2020) <https://economy.okezone.com/read/2020/02/20/320/2171484/bicatat-penggunaan-uang-elektronik-tumbuh-172-85>, dikunjungi pada tanggal 26 Maret 2021.

Herlina Kartika Dewi, 'Rumuskan uang digital, BI akan bikin Central Bank Digital Currency (CBDC)', (Kontan Nasional, 2021) <https://nasional.kontan.co.id/ news/rumuskan-uang-digital-bi-akan-bikin-central-bank-digital-currency$c b d c$. $>$, dikunjungi pada tanggal 28 Maret 2021. 
Jonas Gross, 'CBDC pioneers: Which countries are currently testing a retail central bank digital currency?', (University of Bayreuth, 2020) <https://jonasgross. medium.com/cbdc-pioneers-which-countries-are-currently-testing-a-retailcentral-bank-digital-currency-49333be477f4\#: : text=Our\%20analysis\%20 shows\%20that\%20China,pioneers\%20in\%20the\%20CBDC\%20space.>, dikunjungi pada tanggal 28 Maret 2021.

\section{Artikel}

Badan Standarisasi Nasional, ISO IEC 27001 Teknologi Informasi - Teknik Keamanan - Sistem Manajemen Keamanan Informasi, 2009.

Bank for International Settlements, 'Central bank digital currencies: foundational principles and core features', 2020.

Bank for International Settlements, 'Committee on Payments and Market Infrastructures: Digital currencies', 2015.

Bank for International Settlements, 'Guidance on cyber resilience for financial market infrastructures', 2016.

BSSN, Pengaturan Cybersecurity di Indonesia, 2020.

Agustin Carstens, 'Digital currencies and the future of the monetary system', Hoover Institution policy seminar, 2021.

David Lee Kuo Chuen \& Linda Low, 'Inclusive Fintech: Blockchain, Cryptocurrency, and ICO', World Scientific Publishing, Singapura, 2018.

Mohammad Davoodalhosseini, et.al., CBDC and Monetary Policy, Bank of Canada Staff Analytical Note, Canada, 2020.

IBM \& OMFIF, 'Central bank digital currencies - A collaboration between OMFIF and IBM Blockchain World Wire', United Kingdom, 2018.

Zafar Kazmi, Jaafar Alghazo, \& Ghazanfar Latif, 'Cyber Security Analysis of Internet Banking in Emerging Countries: User and Bank Perspectives', 2017 4th IEEE International Conference on Engineering Technologies and Applied Sciences (ICETAS), 2017.

Antony Lewis, 'The Basics of Bitcoins and Blockchains: An Introduction to Cryptocurrencies and the Technology that Powers Them', Mango Publishing, Florida, 2018. 


\section{Peraturan Perundang-undangan}

Undang-Undang Nomor 7 Tahun 1992 tentang Perbankan sebagaimana telah diubah dengan Undang-Undang Nomor 10 Tahun 1998 (Lembaran Negara Republik Indonesia Nomor 182, Tambahan Lembaran Negara Republik Indonesia Nomor 3472 dan 3790)

Undang-Undang Nomor 23 Tahun 1999 tentang Bank Indonesia (Lembaran Negara Republik Indonesia Nomor 66, Tambahan Lembaran Negara Republik Indonesia Nomor 3843)

Undang-Undang Nomor 3 Tahun 2011 tentang Transfer Dana (Lembaran Negara Republik Indonesia Nomor 39, Tambahan Lembaran Negara Nomor 5204)

Undang-Undang Nomor 7 Tahun 2011 tentang Mata Uang (Lembaran Negara Republik Indonesia Nomor 64, Tambahan Lembaran Negara Republik Indonesia Nomor 5223)

Peraturan Bank Indonesia Nomor 17/8/PBI/2015 tentang Pengaturan dan Pengawasan Moneter (Lembaran Negara Republik Indonesia Nomor 121, Tambahan Lembaran Negara Republik Indonesia Nomor 5703)

Peraturan Bank Indonesia Nomor 18/40//PBI/2016 tentang Penyelenggaraan Pemrosesan Transaksi Pembayaran (Lembaran Negara Republik Indonesia Nomor 236, Tambahan Lembaran Negara Republik Indonesia Nomor 5845)

Peraturan Bank Indonesia Nomor 19/12/PBI/2017 tentang Penyelenggaraan Teknologi Finansial (Lembaran Negara Republik Indonesia Nomor 245, Tambahan Lembaran Negara Republik Indonesia Nomor 6142)

Peraturan Bank Indonesia Nomor 20/6/PBI/2018 tentang Uang Elektronik (Lembaran Negara Republik Indonesia Nomor 70, Tambahan Lembaran Negara Republik Indonesia Nomor 6203)

Peraturan Bank Indonesia Nomor 22/23/PBI/2020 tentang Sistem Pembayaran (Lembaran Negara Republik Indonesia Nomor 311, Tambahan Lembaran Negara Republik Indonesia Nomor 6610) 